\title{
PEMBELAJARAN KONTRUKTIVISTIK BERBASIS LITERASI BARU DALAM PENDIDIKAN AGAMA ISLAM
}

\author{
Ummu Kulsum \\ FAI Universitas Islam Madura (UIM) Pamekasan \\ Email: ummukulsum687@gmail.com
}

\begin{abstract}
The constructivist learning model is formulated in three problem formulations, 1) What is the new literacy-based contructivist learning model in Islamic Education? 2) What is the concept of transmission from constructive-based learning to new literacy in Islamic Education? 3) What is the strategy for transforming constructivist learning based on new literacy in Islamic Education? The aim is to describe the learning model, and also describe the concept of transmission from learning and analyze the strategies of transformational constructivist learning based on new literacy in Islamic religious education. The method uses the inductive qualitative literature method, to explain the results of several scientific works then reduced to a finding by developing existing findings into an innovation and invasion for the development of Islamic religious education. The findings are in the form of PAI learning strategies using constructivistic learning models and new literacy theories that produce reflection meta-cognition for students. Constuctivistic learning needs to be developed also in the affective domain in order to be able to provide changes in the character of students so that students feel a change in him every PAI subject matter is given to him.
\end{abstract}

Keyword: Constructivist Learning, New Literacy, PAI Subjects

\begin{abstract}
Abstrak
Model pembelajaran konstruktivistik dirumuskan pada tiga rumusan masalah, 1) Bagaimana model pembelajaran kontruktivistik berbasis literasi baru dalam Pendidikan Agama Islam, 2) Bagaimana konsep tranmisi dari pembelajaran konstruktivistik berbasis literasi baru dalam Pendidikan Agama Islam?, 3) Bagaimana strategi transformasi pembelajaran konstruktivistik berbasis literasi baru dalam Pendidikan Agama Islam? Tujuannya untuk mendiskripsikan model pembelajarannya, dan juga mendiskripsikan konsep tranmisi dari pembelajarannya serta menganalis strategi transformasi pembelajaran konstruktivistik berbasis literasi baru dalam pendidikan agama Islam. Metodenya menggunakan metode literatur kualitatif induktif, untuk memaparkan hasil dari beberapa karya ilmiah kemudian direduksi menjadi sebuah temuan dengan cara mengembangkan hasil temuan yang telah ada menjadi sebuah inovasi dan invansi untuk pengembangan pendidikan agama Islam. Hasil temuan yang ada berupa strategi pembelajaran PAI dengan menggunakan model pembelajaran konstruktivistik dan teori literasi baru yang menghasilkan meta cognition berupa reflection of action untuk siswa. Pembelajaran konstuktivistik perlu dikembangkan juga dalam ranah afektif agar mampu memberikan merubah karakter siswa sehingga siswa merasakan adanya perubahan dalam dirinya setiap materi pelajaran PAI diberikan kepadanya.

Kata Kunci : Pembelajaran Konstruktivistik, Literasi Baru, Mata Pelajaran PAI
\end{abstract}




\section{A. Pendahuluan}

Dasar utama dari pembelajaran kontruktivistik adalah Siswa belajar membangun interpretasi diri terhadap dunia nyata melalui pengalamanpengalaman baru dan interaksi sosial. Hal ini merupakan pengetahuan yang melekat pada dirinya dapat dipergunakan (memahami kenyataan) serta mereka mempercayai bahwa dirinya sebagai individu yang dapat memaknai kehidupan dalam dunia secara bebas, pendapat ini disampaikan oleh Lav Vygotsky (Yamin, 2013:12). Pembelajaran kontruktivistik merupakan model pembelajaran yang digunakan untuk menemukan temuan baru (invention) atau inovasi baru yang berupa konsep dari inisiatif siswa itu sendiri. hal ini merupakan pendapat dari Brooks and Brooks (Hanafiah dan Suhana, 2012:62). Disisi lain kontruktivistik diyakini sebagai pengetahuan (knowlegde) tentang sesuatu yang merupakan kontruksi (bentukan) oleh subyek yang (akan, sedang dalam proses) memahami sesuatu itu (Yamin, 2013:18).

Temuan baru (invention) itu berupa mediasi pembelajaran yang dihubungkan dengan literasi baru dalam Pendidikan Agama Islam, yang mana literasi baru diharapkan siswa menekuni pendidikan bukan hanya sekader materi pelajaran yang berupa pengetahuan (kognitif), tetapi juga sikap (afektif) dan keterampilan (psikomotor) berupa kompetensi dan skill (ahli) dari pendidikan dasar, dan menengah. Hal ini dilakukan agar siswa dipersiapkan secara kompetensi dan skill untuk menghadapi era digital dan industri 4.0. Literasi baru yang dimaksud: 1) Literasi data, adalah Kemampuan untuk membaca, analisis, dan mempergunakan informasi (Big Data) di era digital. 2) Literasi Teknologi adalah Memahami cara kerja mesin, aplikasi teknologi (Coding, Artificial Intelligence, \& Engineering Principles). 3) Literasi Manusia, adalah Humanities, Komunikasi \& Desain (Ahmad, 16 Pebruari 2018).

Teori Jean Piaget merupakan perkembangan kognitif yang dibentuk oleh individual melalui pengetahuan yang berinteraksi dengan lingkungan yang terdiri dari atas tiga bentuk pengetahuan yaitu a) fisik, b) logika matematik, c) sosial, sedangkan pembentukan pengetahuan ada tiga fase yaitu a) eksplorasi, b) pengenalan konsep, c) aplikasi konsep. Proses pengembangan dari teori Piaget 
adalah menguraikan tentang interaksi antara pengalaman (asimilasi) dan struktur kognitif yang timbul berupa akomodasi. Lev Vygotsky memiliki perhatian dalam bidang lingkungan sosial yang mempunyai pengaruh terhadap pengetahuan diri pada anak. (Danoebroto, 2015:191). Teori Piaget dan Vygotsky ini menjadi tumbuh kembangnya aliran konstruktivistik. Rumusan masalah terdiri dari 3 bagian antara lain: 1) Bagaimana model pembelajaran kontruktivistik berbasis literasi baru dalam Pendidikan Agama Islam?, 2) Bagaimana konsep tranmisi dari pembelajaran konstruktivistik berbasis literasi baru dalam Pendidikan Agama Islam?, 3) Bagaimana strategi transformasi pembelajaran konstruktivistik berbasis literasi baru dalam Pendidikan Agama Islam?

\section{B. Landasan Teori}

1. Pengertian Pembelajaran

Pembelajaran adalah serangkaian kegiatan yang melibatkan informasi dan lingkungan yang disusun secara terencana untuk memudahkan siswa dalam belajar (Suprihatiningrum, 2016: 75). Pembelajaran merupakan suatu sistem, yang terdiri dari berbagai komponen yang saling berhubungan satu sama lain. komponen tersebut antara lain : a) Tujuan, b) Materi, c) Metode, dan d) Evaluasi. Keempat komponen pembelajaran tersebut saling terkait satu sama lain, dan hal ini perlu diperhatikan oleh guru dalam menetapkan dan menentukan metode-metode pembelajaran. Gambar dibawah ini merupakan hasil imajinasi dari kami, karena keempat komponen merupakan satu kesatuan sehingga manjadi sistem tranmisi pembelajaran yang diberikan kepada siswa dan sistem ini selalu ditinjau setiap semesternya.

\section{Gambar 1. Sistem Tranmisi Pembelajaran Kepada Siswa}

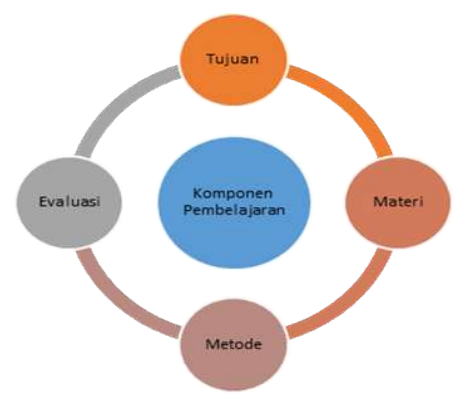

Sumber: Kulsum, 2018. 
Sistem adalah suatu susunan yang berfungsi dan bergerak, maka yang dimaksudkan adalah suatu susunan dari relasi-relasi yang ada pada suatu realitas (Koentjaraningrat, 1991:6), dalam hal ini relasi dari tranmisi pembelajaran kepada siswa yang diberikan kepada siswa melalui sistem komponen pembelajaran, yang didalamnya ada metode yang menyangkut cara kerja yaitu cara kerja untuk dapat memahami obyek yang menjadi sasaran ilmu (Koentjaraningrat, 1991:7), yang sudah ditetapkan dalam proses pembelajaran di kelas. Penggunaan metode pembelajaran di kelas belum cukup memadai karena masih membutuhkan model pembelajaran agar kelas semakin efektif dan proses belajar mengajar memberi ruang buat guru dan siswa dalam berkomunikasi tidak lagi satu arah, tetapi bisa dua arah dan bisa juga komunikasi antar siswa dan guru mampu menciptakan suasana kelas menambah semangat bagi siswa dalam menerima tranmisi ilmu dari guru.

2. Model Pembelajaran

Model pembelajaran adalah sebuah metodologi atau piranti untuk melaksanakan perubahan. Peran guru mestinya seorang profesional yang menjalankan fungsinya dengan menggunakan metodologi untuk menyampaikan materi kepada siswa dengan cara yang tidak konstan, maksudnya guru harus berinovasi dan menciptakan perubahan yang baik pada dirinya atau pada siswa dengan meninggalkan paradigma lama dan beralih dengan menggunakan paradigma baru pembelajaran (Yamin, 2013:12). Jadi model tersebut merupakan pola yang umum bagi pembelajaran untuk bisa memiliki kompetensi atau tujuan pembelajaran yang diharapkan, pendapat Joyce dan Weil, menjelaskan bahwa model pembelajaran adalah rencana atau pola (desain) yang bisa dipakai untuk membuat kurikulum dan pembelajaran jangka panjang, mendesain bahan yang ada untuk membuat pembelajaran dan memberikan (mengarahkan) pembelajaran di dalam kelas atau luar kelas. Model pembelajaran bisa dijadikan pola pilihan, maksudnya para guru atau guru PAI (Pendidikan Agama Islam) bisa menggunakan berbagai model pembelajaran yang sesuai dengan materi ajar dan efisiensinya untuk mencapai tujuan pendidikan yang dimaksud. 
Sebelum menetapkan model pembelajaran yang akan ditetapkan dalam proses KBM di kelas, ada beberapa patokan yang menjadi pertimbangan guru dalam menentukan model pembelajaran, diantaranya: a) menetapkan tujuan yang akan dicapai, b) menetapkan yang berkenaan dengan bahan ajar atau materi pembelajaran, c) menentukan dari pandangan siswa, d) mempertimbangkan hal yang nonteknis (Rusman, 2013:133-134). Dalam menentukan model pembelajaran perlu juga disesuaikan dengan kebutuhan stake holders karena menyangkut out put dan out come yang akan dibutuhkan namun juga disesuaikan dengan kurikulum 2013 atau K 13. Untuk K 13 menggunakan pendekatan kontruktivistik sehingga dengan pendekatan tersebut disesuaikan dengan model pembelajaran kontruktivistik.

3. Pembelajaran Kontruktivistik

Dasar utama dari pembelajaran kontruktivistik adalah Siswa belajar membangun interpretasi diri terhadap dunia nyata melalui pengalamanpengalaman baru dan interaksi sosial. Hal ini merupakan pengetahuan yang melekat pada dirinya dapat dipergunakan (memahami kenyataan) serta mereka mempercayai bahwa dirinya sebagai individu yang dapat memaknai kehidupan dalam dunia secara bebas, pendapat ini disampaikan oleh Lav Vygotsky (Yamin, 2013:12).

Pembelajaran kontruktivistik merupakan pendekatan baru dalam proses pembelajaran yang memiliki karakteristik sendiri sebagaimana dibawah ini : a) Proses pembelajaran berpusat kepada siswa sehingga siswa diberi kesempatan yang besar untuk aktif dalam kegiatan pembelajaran, b) kegiatan pembelajaran adalah proses terpadunya pengetahuan baru dengan yang lama, yang diperoleh siswa. c) dengan cara pandang berbeda yang didapat siswa dihargai dan itu bagian dari tradisi dalam kegiatan proses pembelajaran. d) siswa diberikan motivasi untuk menemukan berbagai apa saja dan mensintesiskan secara terpadu. e) kegiatan pembelajaran berbasis masalah dalam rangka memberi semangat kepada siswa dalam proses pencarian (inquiry) yang lebih nyata. f) kegiatan pembelajaran memberi semangat untuk terjadinya kerjasama dan bersaing yang sehat diantara siswa secara aktif, kreatif, dan inovatif, serta menyenangkan. g) kegiatan pembelajaran dikerjakan secara kontekstual, 
maksudnya siswa dihadapkan ke dalam kehidupan nyata. (Hanafiah dan Suhana, 2012:63-64).

Invensi dan Inovasi terdiri dari dua bagian, bagian satu adalah ide, bagian dua adalah eksekusi. Dengan demikian, mereka cenderung menghasilkan banyak sekali ide di atas kertas yang tidak pernah menjadi sesuatu yang lebih dari ... gagasan di atas kertas. Bagian dua, eksekusi inovasi, adalah disiplin uniknya sendiri. Itu membutuhkan waktu, energi dan pemikiran yang berbeda (Govindarajan dan Trimble, 2013:3).

Pendekatan kontruktivistik ini, tentunya menuntut pembelajaran tentang pemahaman makna dari literasi baru ini bagi pendidikan Islam sendiri. Hal ini agar siswa mampu menghadapi tantangan global dengan mempersiapkan diri secara kompetensi dan skill yang akan dihadapi, sehingga nilai kebermanfaatan, baik dari pendekatan kontruktivistik dan literasi baru memberikan suatu ilmu pengetahuan yang terbarukan untuk masa depan mereka. Temuan baru (invention) bagi siswa adalah ilmu pengetahuan mengenai era digital dan industri 4.0 dipahami secara seksama, dan memahami nilai dan mempelari proses melalui literasi baru yang merupakan sebuah kebutuhan dan keharusan yang harus disampaikan dalam menghadapi tantangan baru di masa depan.

4. Pembelajaran Kontruktivistik Berbasis Literasi Baru

Pembelajaran kontruktivistik, yang digunakan dalam kurikulum menggunakan literasi baru sebagai langkah orientasi baru dalam menghadapi tantangan dan bisa bersaing secara kompetitif di masa yang akan datang. Terutama sekali dalam materi pelajaran Pendidikan Agama Islam teruntuk bagi pendidikan dasar, dan pendidikan menengah. Literasi baru adalah kompetensi dan skill yang dimiliki peserta didik melalui literasi data; yang dapat menguasai big data, literasi teknologi; yang dapat memahami cara kerja mesin dan aplikasi terhadap teknologi dan literasi manusia; memiliki sifat humanities, bisa berkomunikasi dan mendesain dalam memasuki era digital dan revolusi industri 4.0.

Pembelajaran konstruktivistik dan literasi baru bisa dijadikan sebuah teori baru untuk pengembangan pendidikan dasar dan menengah, karena 
tahapan dari pendidikan yang dimulai dari in-put, proses, dan out put, perlu dilakukan untuk mentrasformasi ilmu yang dimiliki kepada siswa, sehingga input yang diterima siswa bisa menjawab kebutuhan zaman dan juga siswa bisa berperan aktif di sekolah dan masyarakat.

5. Desain Model Pembelajaran Kontruktivistik Berbasis Literasi Baru

Model pembelajaran kontruktivistik berbasis literasi baru, merupakan sebuah terobosan baru dalam mata pelajaran Pendidikan Agama Islam (PAI) masa sekarang dan masa yang akan datang. Sebuah gambaran baru tentang desain pembelajaran konstruktivistik yang merupakan perpaduan dua teori yaitu teori Piaget dan teori Vygotsky. Model pembelajaran ini dirancang untuk memberikan sebuah alternatif kepada guru PAI agar dalam menyampaikan materi ajar, guru PAI diharapkan mengikuti perkembangan pendidikan dari segi model pembelajaran. salah satu alternatif model pembelajaran yang kekinian adalah pendekatan kontruktivistik. Sementara literasi baru, merupakan pengetahuan baru yang berbeda dengan literasi lama. Karena kalau literasi lama siswa hanya dituntut bisa calistung (membaca, menulis dan berhitung) sedangkan literasi baru siswa diharapkan dengan adanya komputer, tablet dan HP bisa digunakan sebagai alat pembelajaran baru untuk mendapatkan materi ajar, sehingga kegiatan pembelajaran bisa memberikan ilmu baru kepada siswa, dan siswa diharapkan bisa menyelesaikan masalah dengan urutan sebagai berikut:

\section{Gambar 2 Desain Pembelajaran Kontruktivistik Berbasis Literasi Baru}

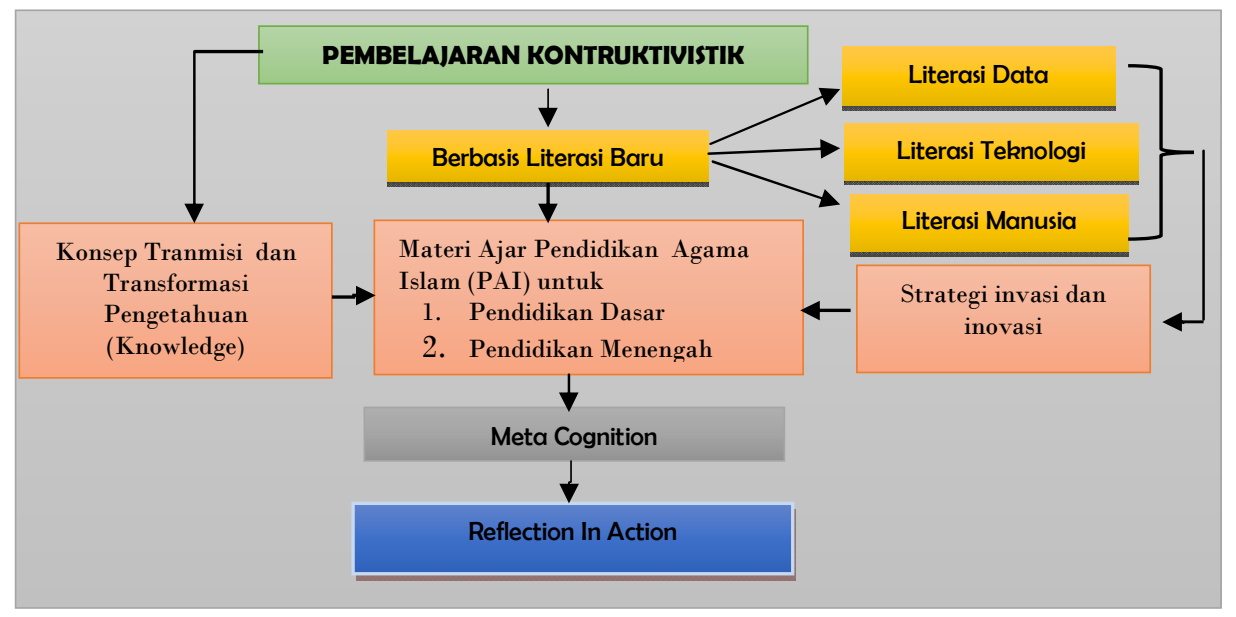

Sumber: Kulsum, 2018. 
Teori pembelajaran konstruktivis (Constructivist Theories Learning) merupakan teori baru dalam psikologi pendidikan, teori ini merupakan tranmisi pengetahuan (knowledge) bagi siswa yang kami kategorikan sebagai berikut, sebagai yang dikutip oleh trianto, a) siswa diharapkan menemukan dan mentransformasikan informasi secara kompleks, b) siswa dapat mengecek informasi baru dengan aturan-aturan yang ada c) siswa dapat merevisi ulang apabila aturan tersebut tidak sesuai lagi untuk kondisi sekarang. Bagi siswa agar bisa memahami dan dapat menerapkan pengetahuan ( knowledge) yang dipelajari, maka a) siswa perlu belajar memecahkan masalah sesuai dengan batas kemampuannya, b) siswa dapat menemukan segala hal untuk dirinya sendiri, c) siswa berusaha dengan baik dengan ide-ide yang dimiliki untuk bisa memecahkan masalah. Teori ini merupakan pengembangan dari teori Piaget, dan Vygotsky (Trianto, 2007:13).

Menurut Teori konstruktivis, untuk transformasi penyampaian materi ajar oleh guru, kami menggunakan tulisan Trianto sebagai alat proses tersebut, yang mana tulisan ini adalah: a) guru jangan hanya memberikan ilmu pengetahuan (kognitif) kepada siswa karena siswa perlu mengimplementasikan sendiri pengetahuan yang didapat di kelas. b) Guru dapat memberikan peluang kepada siswa untuk proses ini, siswa dapat berinovasi atau menerapkan inovasinya sendiri, c) Guru mengajarkan siswa untuk memiliki kesadaran penuh dan menggunakan cara siswa belajar untuk dirinya sendiri (Trianto, 2007:13).

Langkah penting yang perlu dilakukan oleh guru PAI, siswa diharapkan memiliki pengalaman sendiri dan berinteraksi dengan lingkungaannya yang dilakukan diluar kelas merupakan bagian mengkontruksi diri dimana siswa dapat belajar dari pengalaman dirinya dan pengalaman orang lain. pengalaman yang didapat oleh siswa diluar kelas akan tercatat dan terbangun dalam bentuk gagasan-gagasan dan tanggapan-tanggapan. Gagasan dan tanggapan itu akan tertuang dalam kata-kata yang kemudian disampaikan kepada orang lain yang mendengarkan ceritanya.

Dengan demikian pengalaman dan interaksi siswa dapat dipresentasikan kepada orang lain dan orang lain itu mengerti apa yang telah diceritakannya sehingga orang yang mendengarkan cerita tersebut terbawa dengan apa yang telah 
diceritakan tersebut. Satu hal yang perlu diketahui bahwa pengalaman itu menciptakan gagasan dan tanggapan yang bersifat mental, cerita itu juga menciptakan komunikasi dengan dua arah yang seakan-akan ia ikut merasakan, melihat, mengamati dan menikmati secara mental. Jadi kemampuan dalam knowledge (pengetahuan) manusia dapat menghadirkan kenyataan di dalam dirinya, karena semakin banyak respon dan ide yang dimiliki siswa maka semakin banyak dan luas pengetahuan siswa tersebut. Oleh karena itu, kontruksi pengetahuan itu harus dikembangkan melalui belajar. Paparan ini menurut kaum konstruktivistik, menjelaskan bahwa pengalaman dan interaksi dengan orang lain, mampu melahirkan gagasan baru dan semakin luas pengetahuan yang dimiliki (Yamin, 2013:14)

Guru diharapkan bisa berpartisipasi dalam mendidik siswa agar dapat terbentuk pengetahuannya dalam membuat makna, mencari kejelasan, bersikap kritis dan mengadakan justifikasi. Dengan demikian mengajar adalah suatu bentuk dorongan untuk membentuk pengetahuan baru peserta didik (Yamin, 2013:14). Salah satunya yaitu pembelajaran konstruktivistik berbasis literasi baru yang dibutuhkan adalah terbentuknya SDM yang humanis dengan memiliki kemampuan mengakses big data dan menggunakan sandi (coding) sebagai media dalam mengakses data sebagai langkah untuk menyelesaikan suatu masalah yang terjadi di masyarakat. Terkait dengan materi ajar PAI, setiap tahap materi ajar yang ada di buku panduan PAI, siswa diminta mencarikan contoh yang terjadi di masyarakat dan dicarikan solusi berdasar materi yang ada dalam buku panduan PAI.

Paradigma dari pembelajaran konstruktivistik yang melandasi timbulnya kognitif disebut teori meta cognition. Meta cognition merupakan keterangan yang dimiliki oleh siswa dalam mengatur dan mengontrol proses berpikirnya.Menurut Preisseisen, meta cognition meliputi empat jenis keterampilan, antara lain: a) Keterampilan pemecahan masalah (Problem solving) yaitu keterampilan siswa dengan melalui proses berpikir untuk memecahkan masalah melalui pengumpulan fakta-fakta, analisis informasi, menyusun berbagai alternatif pemecahan, dan memilih pemecahan masalah yang paling efektif. b) keterampilan pengambilan keputusan (Decisian making) keterampilan siswa dengan melalui proses berpikir 
untuk memilih suatu keputusan yang terbaik dari beberapa pilihan yang ada melalui pengumpulan informasi, perbandingan perbaikan dan kekurangan dari setiap alternatif, analisis informasi, dan pengambilan keputusan yang terbaik berdasarkan alasan yang rasional. c) keterampilan berpikir kritis (Critical Thinking) keterampilan siswa melalui proses berpikir untuk menganalisa argumen, dan memberikan interpretasi berdasarkan persepsi yang benar dan rasional, analisis asumsi dan bias argumen dan interpretasi logis. d) Keterampilan kreatif (Creative Thinking) keterampilan siswa melalui proses berpikir untuk menghasilkan gagasan yang baru, konstruktif berdasarkan konsep dan prinsip yang rasional, persepsi dan intuisi individu (Yamin, 2013:20). Keempat jenis keterampilan ini, saling terkait satu dengan lainnya, dan sukar membedakannya karena keterampilan ini terintegrasi satu sama lainnya, sehingga apabila menetapkan sebuah keputusan maka keempat jenis keterampilan tidak dapat dibedakan satu sama lainnya karena terintegrasi.

Paradigma konstruktivistik dan teori meta cognition melahirkan prinsip reflection in action. Reflection in action adalah prinsip refleksi dari pengalaman praktisi profesional dalam pemecahkan masalah yang pernah dihadapi untuk memecahkan masalah baru. Proses reflection in action ini merupakan gambaran mengenai proses belajar. Johnson menjelaskan bahwa siswa yang belajar melalui aktifitas atau pekerjaan sendiri dan kemudian mengkaji ulang dari pekerjaan yang dilakukannya. Refleksi dari perilaku yang dilakukan oleh siswa menjadi suatu petunjuk bagi perilaku yang berikutnya.

\section{Metode Penelitian}

Metode ini menggunakan metode literatur dengan pendekatan kualitatif, model penggunaan dengan tinjauan pustaka yang disajikan untuk menjelaskan kerangka teoritis-kronologis masalah penelitian. Dalam hal ini, penggunakan peta Janovec yang menggambarkan model hierarkis, dengan prinsip-prinsip rancangan peta yang sangat baik, antara lain: 


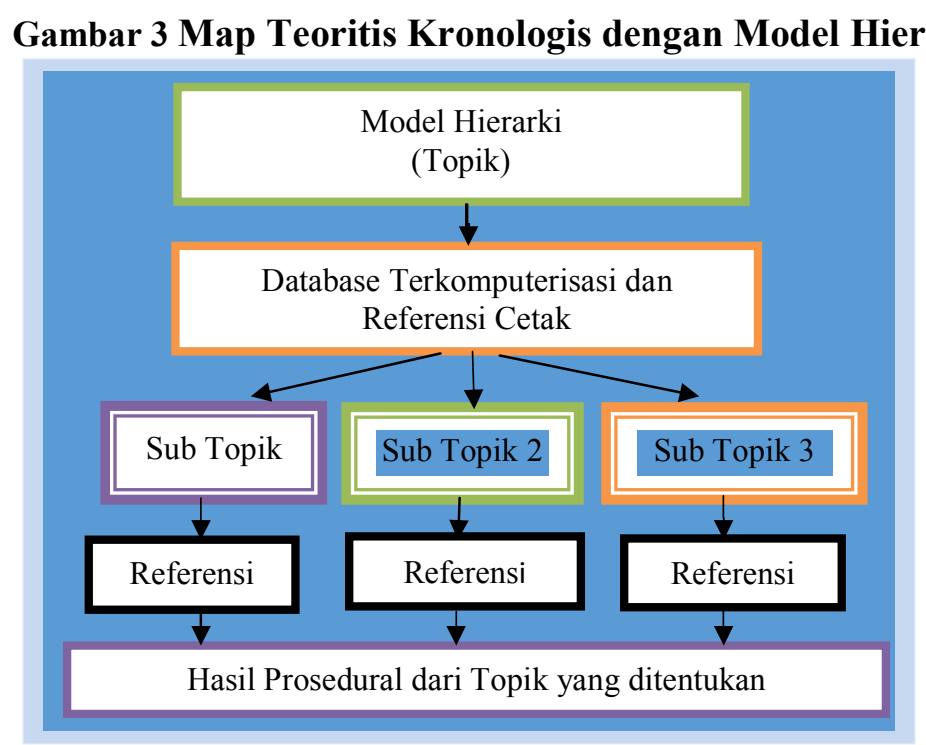

Sumber: Kulsum, 2018.

Kerangka teoritis kronologis dengan model hierarki, merupakan pengembangan dari penulisan penelitian literatur yang ditulis oleh Janovec yang diliris kembali oleh Creswell (Creswell, 2015:55-56). Model hierarki, pada dasarnya mempermudah untuk menulis artikel ilmiah dengan katagori penelitian literatur melalui pendekatan kualitatif induktif. Hasil prosedural dari topik yang ditentukan merupakan hasil a) Topik yang telah ditentukan dari awal penulisan artikel, b) Pencarian data topik melalui database komputerisasi dan referensi cetak, sebagai awal dari sebuah rancangan artikel. c) untuk menetapkan sub topik dari topik yang telah ditentukan, dengan penentuan sub topik tersebut juga diperlukan referensi lanjutan untuk memperdalam dan menajamkan hasil analisis dari pemaparan argementasi dari para penulis jurnal dan referensi cetak. Apabila dibutuhkan sub topik lanjutan ini juga menambah referensi kembali sehingga hasil dari sebuah artikel bisa dipertanggungjawabkan bagi halayak pembaca sebuah artikel.

\section{Hasil}

Pembelajaran konstruktivistik merupakan paradigma baru dalam menyampaikan materi pelajaran di tingkat pendidikan dasar dan menengah, karena guru PAI selama ini, dalam KBM masih bersifat kognitif domain, masih 
bersifat individu, diperuntukkan hanya untuk diri pribadi, sehingga kurang bersinergi dengan apa yang terjadi di masyarakat. Bahkan terkadang kurang merespon dengan segala bentuk kejadian yang ada di masyarakat.

Melalui strategi pembelajaran PAI dengan menggunakan model konstruktivistik dalam proses pembelajarannya, sementara dalam menyiapkan materi pelajaran menggunakan teori literasi baru sehingga hasil akhir yang didapat sebagaimana gambar 4 di bawah ini, berupa meta cognition. Meta cognition merupakan keterampilan yang dimiliki siswa dalam mengatur dan mengontrol proses berpikirnya. Maka dari itu kami membuat kerangka strategi Pembelajaran PAI guna mempermudah guru dalam KBM di kelas.

\section{Gambar 4 Strategi Transformasi Pembelajaran PAI}

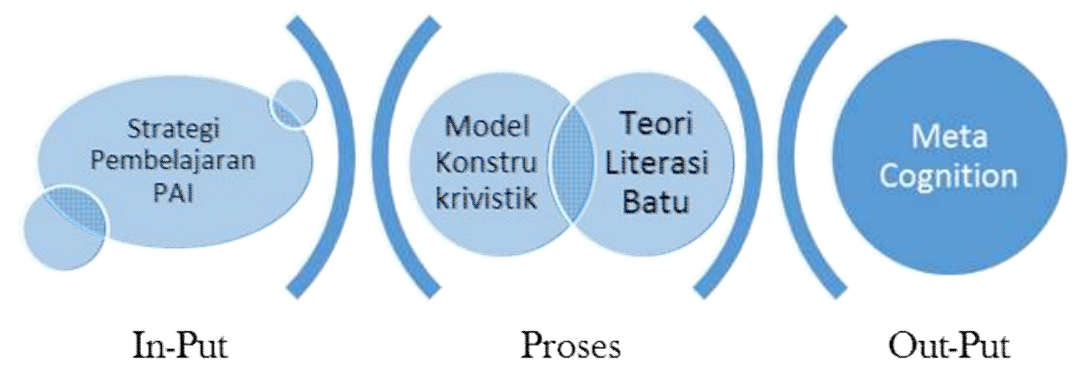

Sumber : Kulsum, 2018.

Meta Cognition, yang menurut Preisseisen, menjelaskan ada 4 jenis keterampilan yang akan diperoleh oleh siswa, diantaranya: a) problem solving, b) decision making, c) critical thinking, dan d) creative thinking, hasil akhir yang bisa diperoleh oleh siswa keempat hal ini, hanya saja keterampilan diatas ini saling terkait satu sama lain dan sukar untuk membedakannya, karena keempatnya tersebut terintegrasi (Yamin, 2013:20).

Proses pembelajaran dengan menggunakan model konstruktivistik dan teori literasi baru, yang akhrinya melahirkan meta cognition dengan versi terbarunya berupa reflection in action. (Yamin, 2013:21). Reflection in Action yang dijalani dengan tetap pada koridor syariah agama yang terkait dengan materi fiqhi, alQur'an hadits, akidah akhlak dan sejarah kebudayaan Islam (SKI). Hasil dari strategi transformasi kami akan bahas secara rinci dalam pembahasan dibawah ini. 


\section{E. Pembahasan}

Mata pelajaran PAI menetapkan materi pokok dalam pembelajarannya seperti: a) materi al-Qur'an Hadist, b) Fiqhi, c) Akidah Akhlak dan d) Sejarah Kebudayaan Islam (SKI). Seiring perjalanan waktu Materi PAI mengalami beberapa perubahan sejalan dengan adanya kurikulum yang ada di Indonesia. Kurikulum pun mengalami pengembangan kurikulum dengan menetapkan perubahan disesuaikan dengan kurikulum yang ada, yang terbaru di mulai tahun 2004, dengan menetapkan kurikulum KBK, kemudian tahun 2006 juga mengalami perubahan yang dikenal dengan KTSP dan kurikulum 2008 dengan pendidikan karakter sebagai standar ukuran, belum juga menemui titik terang baru tahun 2013 dengan penetapan kurikulum 2013 atau dikenal dengan K'13. Arah kebijakannya siswa dianjurkan memiliki kompetensi dan skill (keahlian). Untuk menetapkan dalam proses KBM banyak cara dan metode yang digunakan guna memberikan hasil yang maksimal kepada siswa, salah satu yang digunakan adalah strategi pembelajaran PAI, yang kami bahas dibawah ini :

1. Model Pembelajaran Kontruktivistik Berbasis Literasi Baru dalam Pendidikan Agama Islam

Model pembelajaran sebenarnya banyak sekali, hanya saja penetapan metode yang digunakan kepada siswa perlunya penekanan agar siswa bisa bersifat dan bersikap mandiri, dalam menetapkan hasil pembelajarannya. Hanya saja dibutuhkan kreativitas guru PAI agar siswa terpolarisasi yang disesuaikan dengan kondisi siswa, dalam hal ini perlu kreativitas yang sesuai dengan kurikulum (K'13) yaitu menggunakan pembelajaran konstruktivistik.

Literasi Baru dalam istilah literasi termasuk generasi kelima yang dikenal dengan istilah multiliterasi, yang mengandung pengertian sebagai keterampilan menggunakan beragam cara untuk menyatakan dan memahami ide-ide dan informasi, dengan menggunakan bentuk-bentuk teks konvensional maupun teks inovatif, simbul dan multimedia. Dalam pandangan multiliterasi, siswa dituntut untuk memiliki keahlian dalam memahami dan menggunakan berbagai bentuk teks, media dan sistem simbul untuk memaksimalkan potensi belajar siswa dan juga mengikuti perubahan teknologi dan aktif juga berpartisipasi dalam komunitas global. Dengan demikian, pembelajaran literasi ditujukan untuk 
mengembangkan keterampilan siswa dalam berbagai bentuk literasi seperti literasi visual, literasi media, literasi teknologi dan literasi lintas kurikulum (Abidin dkk, 2018:3-4).

Keterkaitan literasi baru sebagai generasi kelima, dalam mapel PAI, siswa diharapkan bisa membaca situasi yang di masyarakat luas dan memberi respon dengan memberikan solusi dengan mengangkat permasalahan yang terjadi di masyarakat baik melalui multimedia dan memberi respon melalui media juga baik dengan cara website dan blog sebagai media dengan menggunakan pembelajaran konstruktivistik. Dengan model konstruktivistik siswa lebih berperan dalam kelas dengan mengangkat permasalahan yang terjadi di masyarakat yang berkenaan dengan materi ajar PAI.

2. Konsep Tranmisi dari Pembelajaran Kontruktivistik berbasis Literasi Baru dalam Pendidikan Agama Islam

Iyer dan Luke, menyatakan bahwa siswa yang belajar melalui pendekatan multiliterasi (Literasi baru) akan memperoleh pemahaman yang bagus, karena merupakan hasil dari pembelajaran yang proaktif yang dilakukan. disisi lain juga pembelajaran proaktif merupakan pembelajaran yang dikembangkan melalui asas-asas pembelajaran meliputi tahapan mengalami, mengonseptualisasi, menganalisis, dan mengaplikasi. a) Asas Mengalami, memiliki makna bahwa siswa belajar melalui kegiatan memadukan pengetahuan yang telah dimilikinya dengan pengetahuan baru yang dipelajarinya, melalui pembelajaran bermakna. b) Asas Konseptualisasi, memiliki makna bahwa konsep abstrak dan teori disintesiskan melalui proses penamaan dan penteorian. Dalam hal ini akan menjembatani siswa untuk bisa mendefinisikan, mengablikasikan konsep dan memahami generalisasi tentang makna abstrak. Asas Analisis, memiliki makna bahwa pembelajaran dikembangkan dengan cara menganalisis dan menginterpretasikan melalui pengetahuan dan dikritisi dengan analisis yang telah ditetapkan. Asas Aplikasi, memiliki makna bahwa pengetahuan diabstraksikan melalui pemahaman yang dapat diaplikasikan dan diperluas sehingga menghasilkan pengetahuan baru (Abidin, 2018: 11-12). 
Tranmisi pengetahuan yang diterima siswa dilakukan dengan cara pentahapan empat asas yang sudah dipaparkan di atas, sehingga kesinambungan pengetahuan yang di peroleh siswa bisa terkonsep dengan baik dan siswa bisa menerima dengan baik karena dari awal proses pembelajaran guru sudah menjelaskan proses KBM di kelas.

3. Strategi Transformasi Pembelajaran Konstruktivistik Berbasis Literasi Baru dalam Pendidikan Agama Islam

Strategi adalah rencana jangka panjang, diikuti tindakan yang ditujukan untuk mencapai tujuan tertentu, yang umumnya dimaknai dengan "kemenangan" (Sedarmayanti, 2014:2). Strategi belajar, menurut Weinstern dan Meyer, adalah pembelajaran yang baik meliputi mengajarkan siswa bagaimana belajar, bagaimana berpikir dan bagaimana memotivasi diri mereka sendiri (Suprihatiningrum, 2016:48) lihat (Nur, 2005:5). Kata transformasi berasal dari bahasa Inggris transform yang berarti mengendalikan suatu bentuk ke bentuk lain. Transformasi dapat bermakna proses perubahan, dan mengandung arti proses perubahan nilai (Dewi, 2012:112).

Strategi transformasi mengandung makna suatu rencana yang dilakukan melalui proses perubahan nilai untuk mencapai tujuan yang telah ditentukan. Perubahan nilai yang diharapkan siswa setelah melalui proses pembelajaran konstruktivistik memiliki pengalaman baru dalam menghadapi dunia digital dan revolusi industri 4.0 tanpa melepas atribut keislaman yang dia miliki, karena untuk membangun mental spiritual siswa perlu dihubungkan antara materi ajar PAI dengan kehidupan yang terjadi di masyarakat global. Pembelajaran konstruktivistik dijadikan standar sebagai model pembelajaran dengan menggunakan teori literasi baru dalam menyampaikan materi PAI agar siswa mampu menyelesaikan permasalahan yang terjadi di masyarakat, atau paling tidak untuk dirinya sendiri dalam memberikan sikap dengan keilmuan yang dimiliki, dan tidak terbawa arus emosional dengan segala kemungkinan yang terjadi melalui berita media. 


\section{F. Kesimpulan}

Model pembelajaran konstruktivistik merupakan paradigma baru bagi pendidikan Agama Islam di Indonesia, tentunya paradigma yang digunakan dengan cara mereformulasi PAI dengan merenovasi pembelajaran yang digunakan, baik dalam in-put - proses -- out-put menggunakan strategi pembelajaran PAI dengan menggunakan model pembelajaran konstruktivistik dan teori literasi baru dalam mempersiapkan mengajar di depan kelas. Hasil dari strategi pembelajaran PAI mampu melahirkan meta cognition.

Pembelajaran konstuktivistik perlu dikembangkan lagi bukan hanya hanya menyiapkan materi pelajaran dan proses $\mathrm{KBM}$ di kelas tetapi bisa dijadikan strategi pembelajaran yang mampu memberikan perubahan nilai dan karakter siswa sehingga siswa bisa merasakan adanya perubahan dalam dirinya setiap materi pelajaran PAI diberikan kepadanya.

\section{Daftar Pustaka}

Abidin, Yunus. Mulyati, Tita. Yunansah, Hana. 2018. Pembelajaran Literasi: Strategi Meningkatkan Kemampuan Literasi Matematika, Sains, Membaca dan Menulis. Jakarta. Bumi Aksara.

Ahmad, Intan. 2018, Proses Pembelajaran Digital dalam Era Revolusi Industri 4.0. Medan. Kementristek Dikti.

Creswell, John, W. 2015. Research Desaign: Pendekatan Kualitatif, Kuantitatif, dan Mixed (terj). Yogyakarta. Pustaka Pelajar.

Danoebroto, Sri Wulandari, 2015. Teori Belajar Konstruktivis Piaget dan Vygotsky. Jurnal of Matematies and Education. Vol. 2. No 3: 191-198.

Dewi, Ernita. 2012. Transformasi Sosial dan Nilai Agama. Jurnal Substantia, Vol. 14. No 1: $112-121$.

Govindarajan, Vijay. Dan Trimble, Chris. 2013. Beyond The Idea: How to Execute Innovation in Any Organization. New York: St. Martin's Press.

Hanafiah, Nanang. Suhana, Cucu. 2012. Konsep Strategi Pembelajaran. Bandung. Refika Aditama.

Hendrowati, Yuni, Tri. 2015, Pembentukan Pengetahuan Lingkaran Melalui Pembelajaran Asimilasi dan Akomodasi Teori Konstruktivisme Piaget. Jurnal e-Dumath Volume 1, No 1: 1-16.

Koentjaraningrat, 1991. Metode-Metode Penelitian Masyarakat. Jakarta. Gramedia Pustaka Utama.

Kulsum, Ummu. 2011. Metodik Khusus Pendidikan Agama Islam.Yogyakarta. Pustaka Nusantara.

Sedarmayanti, 2014. Manajemen Strategi. Bandung. Refika Aditama.

Suprihatiningrum, Jamli. 2016. Strategi Pembelajaran. Yogyakarta. Ar-Ruzz Media. 
Trianto. 2007. Model-Model Pembelajaran Inovatif Berorientasi Konstruktivistik. Jakarta. Prestasi Pustaka.

Yamin, Martinis. 2013. Paradigma Baru Pembelajaran. Jakarta. Referensi. 